\title{
THE MAKING OF BRITAIN
}

\section{Echoes of Greatness}




\section{THE MAKING OF BRITAIN}

\section{Echoes of Greatness}

edited by

Lesley M. Smith

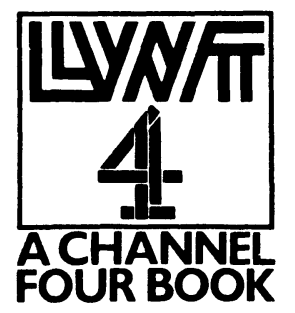

MACMILLAN 
All rights reserved. No reproduction, copy or transmission of this publication may be made without written permission.

No paragraph of this publication may be reproduced, copied or transmitted save with the written permission or in accordance with the provisions of the Copyright Act 1956 (as amended), or under the terms of any licence permitting limited copying issued by the Copyright Licensing Agency, 7 Ridgmount Street, London WC1E 7AE.

Any person who does any unauthorised act in relation to this publication may be liable to criminal prosecution and civil claims for damages.

First published 1988

Published by

MACMILLAN EDUCATION LTD

Houndmills, Basingstoke, Hampshire RG21 2XS

and London

Companies and representatives

throughout the world

Typeset and designed by Columns of Reading

British Library Cataloguing in Publication Data

Echoes of Greatness.-(The Making of Britain)

1. Great Britain-History-20th century

I. Smith, Lesley M. II. Series

941.082 DA566

ISBN 978-0-333-45655-2 ISBN 978-1-349-19180-2 (eBook)

DOI 10.1007/978-1-349-19180-2 


\section{Contents}

List of Illustrations

Acknowledgements

$\mathrm{xi}$

Preface

xiii

Introduction

Lesley M. Smith

1 The Past in the Present

David Cannadine

2 Britannia Overruled: the Shrinking of a World Power David Reynolds

3 The Decline of Britain?

Richard Overy

4 The New Jerusalem John Stevenson

5 A Woman's Place

Pat Thane

6 In Place of Fear

Adrian Wooldridge

7 Mass Media, Mass Democracy

Paddy Scannell

8 People and Power

Kenneth O. Morgan

9 The Myth of Consensus

Ben Pimlott

10 The Dark Strangers 
11 A Prosperous People Leslie Hannah

12 In the Shadow of the Past 173 Michael Ignatieff

Notes 187

Notes on Contributors 201

Index

205 


\section{List of Illustrations}

1.1. Queen Elizabeth II riding the state coach 10

1.2. Keith Michell as Henry VIII 11

1.3. Glenda Jackson as Elizabeth I of England 11

1.4. Brideshead Revisited 12

1.5. A National Trust craftsman restoring plaster work 12

1.6. Princes Risborough, one of the National Trust properties 14

1.7. Exhibit of decorative sanitary ware, Gladstone Working 15 Pottery Museum

Chapter 2

2.1. The Fifth Indian Regiment, Second World War 23

2.2. Mountbatten speaking during the Independence 24 ceremonies, India, 1947

2.3. The King David Hotel, Jerusalem, after the explosion 25

2.4. Bombers, Second World War 26

2.5. The surrender of Singapore, $1942 \quad 30$

2.6. The ruined city of Stuttgart, 1945

2.7. The first meeting of the American and Russian 31 armies, 1945

2.8. Rebuilding Berlin, 1946

2.9. Britain enters the Common Market 33

\section{Chapter 3}

3.1. Unemployed cotton workers, 1952

3.2. Engineering workshop, Coventry, before First World War 40

3.3. Suburban housing, 1930

3.4. Jarrow marchers 42 
3.5. The Morris garage in Oxford, 1902

3.6. The Morris headquarters, $1919 \quad 44$

3.7. The Morris headquarters in the 1920s 46

3.8. An advertisement for Morris cars, 1929

\section{Chapter 4}

4.1. Industrial pollution, $1930 \mathrm{~s}$

4.2. An artist's impression of Letchworth Garden City 58

4.3. One of Letchworth's tree-lined streets 59

4.4. Housing for munitions workers at Well Hall, Eltham 59

4.5. Old Wythenshawe, Manchester 61

4.6. Workers' flats in Vienna, built 1919

4.7. Quarry Hill Flats, Leeds 62

4.8. Bomb damage in Coventry 65

4.9. The choice for the future 65

4.10.The construction of the Parkhill Flats 68

\section{Chapter 5}

5.1. Women at work; a tailoring shop, 1908

5.2. Middle-class women visiting slumdwellers, 1912

5.3. The arrest of a suffragette 78

5.4. Recruiting poster, First World War 79

5.5. Recruiting poster, Second World War $\quad 79$

5.6. Women making munitions, First World War 80

5.7. Cooking at an open range, London, $1940 \quad 81$

5.8. Women among coal strikers in the Bolton area, 1912

5.9. Demonstration in favour of greater equality for women 83

\section{Chapter 6}

6.1. The Boer War $\quad 87$

6.2. The Boeer War 87

6.3. Kaiser Wilhelm II of Germany with his guard 88

6.4. The new generation, $1901 \quad 90$

6.5. An early school meal 90

6.6. A working-class family, Stoke-on-Trent, just after 94 Second World War

6.7. The 'gentlemen in Whitehall' 96 


\section{Chapter 7}

7.1. The Ecko set at Radiolympia, 1935

7.2. The Radio Times issue featuring the Listener Family, 1938101

7.3. The Radio Times Fireside number, 1935

7.4. Family listening to the radio in 1931

7.5. John Reith

7.6. Musicians recording in studio, 1923

7.7. Celebrations in Coronation Street 109

7.8. Ken Barlow: in first episode of Coronation Street 109 (left) and in 1987 (right)

\section{Chapter 8}

8.1. Fabian meeting

8.2. Dockers, 1893

8.3. Ramsay MacDonald as Prime Minister

8.4. The end of the General Strike

8.5. The 'Clydeside Reds'

8.6. The Labour Victory of 1945

8.7. Welsh coalminers during the $1950 \mathrm{~s}$

8.8. Clement Attlee visits the Cup Final as Prime Minister, 1948125

\section{Chapter 9}

9.1. Lady Astor

9.2. Poster encouraging electors to vote for the National Government 1931

9.3. Unemployed men in Manchester, 1938

9.4. Mill girls during their lunch break

9.5. Winston Churchill, 1951

\section{Chapter 10}

10.1. Troops leaving Kingston, 1916

10.2. Second World War: advertisement encouraging West Indian workers to come to Britain

10.3. West Indian pilot, Second World War

10.4. New arrivals from the Caribbean in an air raid shelter near Clapham Common

10.5. The Empire Windrush arrives

10.6. Advertisement for one of the 'lady boats'

10.7. The Family of Sir William Young by Zoffany

10.8. Portrait of Ignatius Sancho by Gainsborough 
10.9. Notting Hill riots, 1958

10.10.Sign on lodgings banning 'coloureds' 159

Chapter 11

11.1. At the seaside, 1940s 162

11.2. A family holiday in Marbella 162

11.3. Schoolyard at the end of the nineteenth century 164

11.4. A modern classroom 164

11.5. Washday at the public laundry 167

11.6. Scrubbing the linoleum 168

11.7. The 1926 vacuum cleaner 169

11.8. Post-war house building for a new generation of $\quad 170$ home-owners

Chapter 12

12.1. The Lavender Hill Mob 175

12.2. A Kind of Loving $\quad 175$

12.3. Mona Lisa 176

12.4. My Beautiful Laundrette 176

12.5. Merthyr Tydfyl 1950s 179

12.6. Multiracial Britain: an anti-apartheid demonstration 182

12.7. Pro-abortion demonstration 183 


\section{Acknowledgements}

The publishers wish to acknowledge the following illustration sources:

The National Trust; Colorific Photo Library Ltd; BBC Enterprises Ltd; Gladstone Pottery Museum; Granada Television; John Frost Historical Newspapers; Popperfoto; Archiv Gerstenberg; BBC Hulton Picture Library; Imperial War Museum; Broadlands Archive; British Motor Industry Heritage Trust; Coventry City Libraries; Bede Gallery; Sheffield City Council; Greenwich Local History Library; Manchester Local History Library; The Keystone collection; Mansell Collection; Leeds City Libraries; First Garden City Heritage Museum; Camera Press Ltd; Bolton Museum and Art Gallery; The British Library; London Transport Museum; Dr Pat Thane; Rowntree plc; The Radio Times; Fabian Society; Wigan Record Office; The Photosource; National Gallery of Canada; National Museums and Galleries on Merseyside; Conservative Research Department; Mary Evans Picture Library; The Kobal Collection; Mike Laye, Daniel Day Lewis and Gordon Warnecke Press Association Ltd.

Every effort has been made to trace all the copyright holders but if any have been inadvertently overlooked the publishers will be pleased to make the necessary arrangement at the first opportunity. 


\section{Preface}

This book accompanies the fifth and final series of LWT/Channel Four's survey of British history, The Making of Britain. I should like to thank all those at London Weekend Television who have been involved with this series: Barry Cox, Jane Hewland, Robin Paxton, whose comments did much to shape the final version of both the series and the book, and Johanna Pool. All the contributors to the book have generously shared with me their knowledge of the twentieth century and brought to our project an enthusiasm which has made this series particularly enjoyable. A number of other scholars have also spent time discussing the twentieth century with me and I should like to thank particularly David Anderson, Linda Colley, Leonore Davidoff, Christopher Harvie, Paul Johnson, Jane Lewis, Sara Maitland, Robert Pearce, and Lavinia Warner. Linda Stradling accomplished the very extensive picture research for both the book and the series with patience and skill. Her efficiency and good humour also helped to keep the project running smoothly over the last months of preparation. I am also grateful to Pam Wilkinson who again typed the manuscript for me. Finally, throughout the five years we have worked on The Making of Britain, Pat Newbert, our Unit Manager in the Features department, and her secretary, Marcelle Ruddell, have done everything they could to solve any problems that arose. In thanks, I should like to dedicate this book to them. 